\author{
${ }^{[0000-0002-4496-2178]}$ О. С. Діброва, \\ Національний університет цивільного захисту України \\ вул. Чернишевського, 94, м. Харків, 61023, Україна \\ ${ }^{[0000-0002-0240-1807]}$ О. В. Кириченко, д.т.н., професор, \\ ${ }^{[0000-0002-5670-6788]}$ Р. Б. Мотрічук, \\ Черкаський інститут пожежної безпеки імені Героїв Чорнобиля \\ Національного університету цивільного захисту України \\ вул. Онопрієнка, 8, м. Черкаси, 18034, Україна \\ ${ }^{[0000-0003-0722-9353]}$ В. А. Ващенко, д.т.н., професор \\ ${ }^{[0000-0002-0234-8655] ~ С . ~ О . ~ К о л і н ь к о, ~ к . ф . .-м . н ., ~ д о ц е н т, ~}$ \\ ${ }^{[0000-0003-3065-5772]}$ T. І. Бутенко, к.т.н., доиент, \\ $[0000-0002-2805-572 X]$ В. В. Цибулін \\ Черкаський державний технологічний університет \\ б-р Шевченка, 460, м. Черкаси, 18006, Україна

\section{ВИЗНАЧЕННЯ КРИТИЧНИХ РЕЖИМІВ РОЗВИТКУ ПРОЩЕСІВ ГОРІННЯ ПІРОТЕХНІЧНИХ НІТРАТНО-МЕТАЛЕВИХ СУМІШЕЙ В УМОВАХ ЗОВНІШНІХ ТЕРМІЧНИХ ДІЙ}

Розроблено модель горіння ущільнених сумішей із порошків Ті та нітратовмісного окиснювача) для визначення критичних режимів їх горіння шляхом розрахунку залежностей швидкості розповсюдження фронту горіння по зарядах від технологічних чинників та зовнішніх умов. Сформульовано механізм та розроблено модель горіння ущільнених сумішей із порошків металевих пальних і нітратів лужних та лужноземельних металів, що враховують кінетику термічного розкладання окиснювача, високотемпературного окиснення, спалахування та повного згоряння частинок металу на поверхні горіння суміші. Вперше за допомогою розробленої моделі для сумімі $\mathrm{Ti}+\mathrm{NaNO}_{3}$ визначено критичні режими розвитку їх горіння в умовах зовнішніх термічних дій, перевищення яких призводить до пожежовибухонебезпечного руйнування піротехнічних виробів.

Ключові слова: піротехнічні суміші, нітратовмісний окиснювач, металеве пальне, процеси горіння, пожежна безпека.

Вступ. При експлуатації піротехнічні вироби різного призначення (освітлювальних снарядів та патронів, трасерів для реактивних снарядів, піротехнічних ІЧ-випромінювачів та ін.) на основі зарядів ущільнених сумішей із порошків металевих пальних ( $\mathrm{Ti}, \mathrm{Mg}, \mathrm{Al}$ та ін.) та нітратовмісних окиснювачів $\left(\mathrm{NaNO}_{3}\right.$, $\mathrm{Ba}\left(\mathrm{NO}_{3}\right)_{2}, \mathrm{Sr}\left(\mathrm{NO}_{3}\right)_{2}$ та ін.) піддаються інтенсивним зовнішнім термічним впливам (наприклад, при пожежах у складських приміщеннях, де зберігаються вироби, або при їх транспортуванні, в умовах пострілу та польоту тощо) [1-14]. В результаті відбувається передчасне спалахування зарядів сумішей і прискорений розвиток процесу їх горіння, який при певних критичних режимах переходить до вибухового горіння $[9,11]$, обумовленого різким зростанням швидкості горіння сумішей, що, у кінцевому підсумку, призводить до пожежонебезпечних руйнувань піротехнічних виробів (рисунки 1-3). Тому важливо знати, як і 3 якою швидкістю відбувається процес горіння зарядів сумішей у зазначених умовах. Останнє необхідне для визначення часів згоряння сумішей залежно від технологічних чинників (співвідношення та дисперсності компонентів, природи металевого пального та нітратовмісного окиснювача) i зовнішніх умов (температури нагріву та зовнішнього тиску), а також для виключення критичних режимів розповсюдження горіння по зарядах сумішей у цих умовах.

Це дає можливість на стадії проектування та стендових випробувань піротехнічних виробів розрахунковим шляхом вибирати критичні режими горіння зарядів сумішей, перевищення яких призводить до пожежонебезпечних руйнувань виробів в умовах їх експлуатації. Нині для розрахунку швидкостей горіння піротехнічних сумішей розроблено та 
докладно досліджено моделі горіння сумішей на основі $\mathrm{Mg}+\mathrm{NaNO}_{3}$ [15-20]. Стосовно інших піротехнічних сумішей, то результати теоретичних досліджень 3 моделювання процесів їх горіння при різних зовнішніх умовах вельми обмежені, а у більшості випадків відсутні.

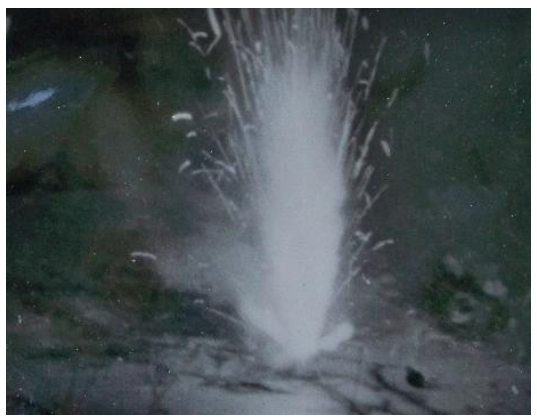

1
Метою роботи є розробка моделі горіння ущільнених сумішей 3 порошків Ті та нітратовмісного окиснювача $\left(\mathrm{NaNO}_{3}\right.$, $\left.\mathrm{Ba}\left(\mathrm{NO}_{3}\right)_{2}, \mathrm{Sr}\left(\mathrm{NO}_{3}\right)_{2}\right)$ для визначення критичних режимів їх горіння шляхом розрахунку залежностей швидкості розповсюдження фронту горіння по зарядах від технологічних чинників та зовнішніх умов.

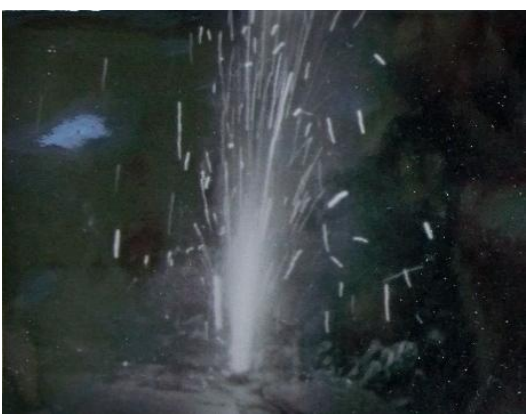

2

1, 2 - початкова та кінцева стадії трасерів (кінозйомка здійснювалася кінокамерою «Конвас-автомат» (швидкість зйомки - 30 кадр/с))

Рисунок 1 - Кінокадри зйомки загальної картини пожежонебезпечних руйнувань серійних трасерів

(білий вогонь на основі заряду нітратно-титанової суміші) для реактивних снарядів в умовах зовнішнього нагріву при різних пожежах

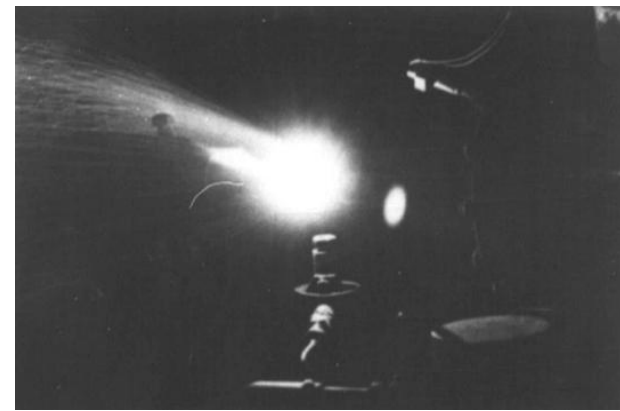

1

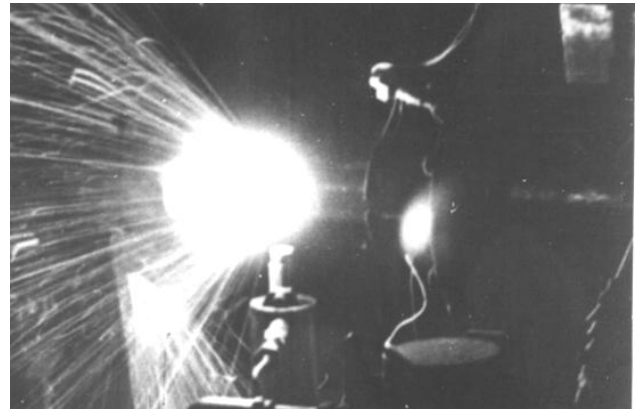

2

1, 2 - початкова та кінцева стадії дії ІЧ-випромінювачів

Рисунок 2 - Кінокадри зйомки загальної картини пожежонебезпечних руйнувань піротехнічних ІЧ-випромінювачів на основі зарядів нітратно-титанових сумішей при зовнішніх термічних діях

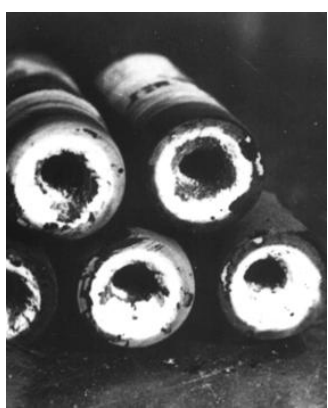

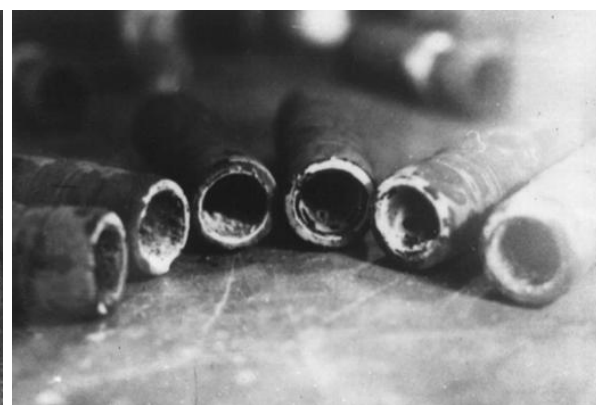

2

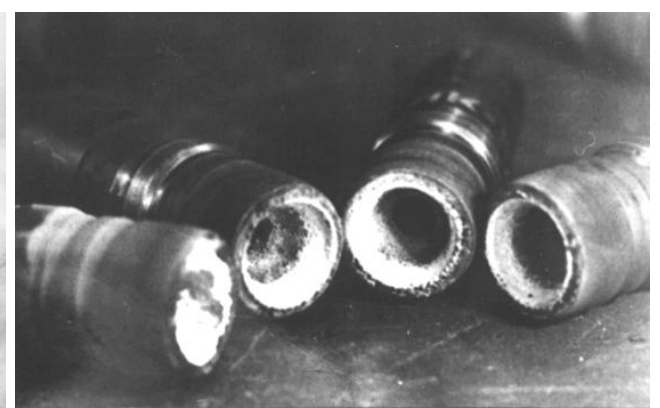

3

1 - суміші з надлишком металевого пального; 2 - стехіометричні суміші;

3 - суміші з надлишком окиснювача

Рисунок 3 - Різні ракурси серійних освітлювальних снарядів на основі зарядів піротехнічних нітратно-титанових сумішей після їх передчасного спрацьовування та пожежонебезпечного руйнування в умовах зовнішніх термічних впливів

(C) О. С. Діброва, О. В. Кириченко, Р. Б. Мотрічук, В. А. Ващенко, С. О. Колінько, Т. І. Бутенко, В. В. Цибулін, 2020 DOI: $10.24025 / 2306-4412.2 .2020 .197339$ 
Результати досліджень та їх аналіз. Проведений аналіз експериментальних відомостей про фізико-хімічні процеси, що проходять у різних зонах горіння розглядуваних сумішей (суміші з $0,3<\alpha<1,4)[9,11]$ дає можливість встановити механізм їх горіння, згідно з яким процес перетворення вихідної суміші в продукти згоряння в першому наближенні $\epsilon$ стаціонарним, одновимірним i проходить в наступних трьох найхарактерніших зонах (рисунок 4). Зона I - прогрітий шар у к-фазі суміші, де можна знехтувати хімічними перетвореннями. Зона II - реакційна зона к-фази суміші, в якій тверда суміш перетворюється на газ, що містить окремі частинки металу. В межах цієї зони відбувається розкладання окиснювача у вигляді розплавленого шару зі значним поглинанням тепла i енергійне окиснення частинок металевого пального по реакціях, для яких $E>R T$. Спалахування частинок металу відбувається на поверхні горіння. Поверхня горіння визначається як площина, на якій тверда суміш втрачає властивості суцільного конденсованого середовища, і характеризується середньою температурою $T_{n}$. Більша частина частинок металу повністю згоряють на цій поверхні, інші диспергуються у г-фазу. Тепло від частинок металу, що згоряють, передається вглиб к-фази. Зона III - зона тепловиділення г-фази. В цій зоні дисперговані частинки металу згоряють у потоці продуктів розкладання окиснювача та органічної речовини, утворюючи продукти згоряння 3 температурою $T_{2}$. Тепло, що виділяється, за допомогою теплопровідності і радіації передається в к-фазу.

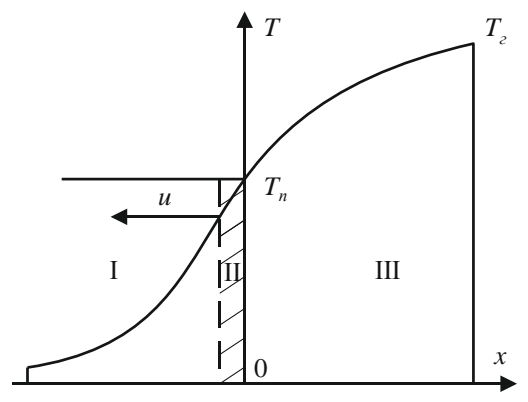

Рисунок 4 - Схема розподілу температури поблизу поверхні розділу фаз суміші

При зазначених вище основних припущеннях про механізм горіння розглядуваних сумішей, а також при припущенні відсутності тепловтрат у навколишнє середовище і зов- нішніх сил розповсюдження фронту реакції горіння в к-фазі вихідної суміші можна описати наступною відомою в теорії горіння [9] системою рівнянь:

$$
\begin{aligned}
& \frac{d}{d x}\left(\lambda_{c} \frac{d T}{d x}\right)-\rho_{c} c_{c} \frac{d T}{d x}-H_{\text {ок }} \rho_{c} u \zeta_{\text {ок }} \frac{d \psi_{1}}{d x}+H_{M} \rho_{c} \zeta_{M} u \frac{d \psi_{2}}{d x}=0 ; \\
& u \frac{d \psi_{1}}{d x}=K_{1} e^{-E_{1} /(R T)} ; \\
& u \frac{d \psi_{2}}{d x}=K_{2} \cdot C_{O_{2}}^{m} \cdot \rho_{2}^{n} e^{-E_{2} /(R T)} \\
& T=T_{n}, \psi_{1}=\psi_{1 n}, \psi_{2}=\psi_{2 n} ; \lambda_{c}\left(\frac{d T}{d x}\right)=q_{n}+q_{\kappa}+q_{R} \text { при } x=0 . \\
& T=T_{0}, \psi_{1}=\psi_{2}=0 \text { при } x \rightarrow-\infty ;
\end{aligned}
$$

Тут $\rho_{c}, c_{c}, \lambda_{c}-$ густина (кг $\left./ \mathrm{M}^{3}\right)$, питома теплоємність (Дж/кг·К) і коефіцієнт теплопровідності $(\mathrm{BT} / \mathrm{M} \cdot \mathrm{K})$ суміші відповідно; $H_{\text {ок }}$ - тепловий ефект реакції розкладання окиснювача (Дж/кг); $\psi_{i}, K_{i}$ та $E_{i}(i=\overline{1,2})$ - відносні ступені розкладання окиснювача й окиснення металевого пального (за масою) та їх кінетичні константи (c ${ }^{-1}$, кДж/моль) відповідно; $\zeta_{\text {ок }}, \zeta_{M}-$ відносні масові вмісти окиснювача та металевого пального в суміші відповідно; $q_{n}-$ тепловий потік від частинок металу, що згоряють на поверхні горіння, Вт/м ${ }^{2} ; q_{k}, q_{R}-$ кондуктивний та радіаційний теплові потоки з зони полум'я відповідно, Вт/м².

Щоб отримати вирази для визначення швидкості горіння, систему (1)-(5) зручно звести до одного рівняння.

Проінтегрувавши рівняння (2) від $-\infty$ до $x$, отримаємо 
$\lambda_{c}\left(\frac{d T}{d x}\right)=\rho_{c} c_{c} u\left(T-T_{0}\right)-H_{M} \rho_{c} \zeta_{M} u\left(\psi_{2}-\frac{H_{\text {ок }} \zeta_{\text {oк }}}{H_{M} \zeta_{M}} \psi_{1}\right)$. (6) Помножимо рівняння (2) на $\frac{H_{\text {ок }} \zeta_{\text {ок }}}{H_{\mu} \zeta_{M}}$, потім віднімемо його від рівняння (3):

$$
u \frac{d}{d x}\left(\psi_{2}-\frac{H_{O K} \zeta_{O K}}{H_{M} \zeta_{M}} \psi_{1}\right)=K_{2} \cdot C_{O_{2}}^{m} \cdot \rho_{2}^{n} \cdot e^{-E_{2} /(R T)}-K_{1} \frac{H_{O K} \zeta_{O K}}{H_{M} \zeta_{M}} e^{-E_{1} /(R T)} .
$$

Розділимо (7) на (6):

$$
\frac{u}{\lambda_{c}} \cdot \frac{d}{d T}\left(\psi_{2}-\frac{H_{O K} \zeta_{O K}}{H_{M} \zeta_{M}} \psi_{1}\right)=\frac{K_{2} \cdot C_{O_{2}}^{m} \cdot \bar{\rho}_{2}^{n} \cdot e^{-E_{2} /(R T)}-K_{1} \frac{H_{O K} \zeta_{K} \zeta_{K}}{H_{M}-E_{1} /(R T)}}{\rho_{c} c_{c} u\left(T-T_{0}\right)-H_{M} \rho_{c} u \zeta_{M}\left(\psi_{3}-\frac{H_{O K} \zeta_{O K}}{H_{M} \zeta_{M}} \psi_{1}\right)} .
$$

Для випадку $E_{\mathrm{i}} \gg>T(i=\overline{1,2})[6,9]$ ро3глядувані реакції розкладання окиснювача 3 утворенням газоподібних продуктів та окиснення в них частинок металу проходять в основному у вузькій реакційній зоні к-фази, що прилягає до поверхні горіння суміші, тобто практично при температурі $T_{n}$. Тоді згідно 3 відомим «методом розкладання експоненти» [11]:

$$
\begin{gathered}
u \frac{d}{x d}\left(\psi_{2}-\frac{H_{O K} \zeta_{O K}}{H_{M} \zeta_{M}} \psi_{1}\right)=\left[K_{2} \cdot C_{O_{2}}^{m} \cdot \rho_{2}^{n} \cdot e^{E_{2} /\left(R T_{n}\right)} \cdot e^{\frac{E_{2} \cdot\left(T_{n}-T\right)}{R T_{n}^{2}}}-K_{1} \cdot \frac{H_{O K} \zeta_{O K}}{H_{M} \zeta_{M}} \cdot e^{E_{1} /\left(R T_{n}\right)} \cdot e^{\frac{E_{1} \cdot\left(T_{n}-T\right)}{R T_{n}^{2}}}\right] \cdot \\
\cdot\left[\rho_{c} c_{c} u\left(T_{n}-T_{0}\right)-H_{M} \rho_{c} u \zeta_{M}\left(\psi_{2}-\frac{H_{O K} \zeta_{o K}}{H_{M} \zeta_{M}} \psi_{1}\right)\right]
\end{gathered}
$$

Рівняння (11) повинне задовольняти граничним умовам

$$
\begin{aligned}
& \psi_{1}=\psi_{2}=0 \text { при } T=T_{0} \text {; } \\
& l_{2}=\psi_{1 n}, \psi_{2}=\psi_{2 n} \text { при } T=T_{n} \text {. } \\
& u^{2}\left[\rho_{c} c_{c}\left(T_{n}-T_{0}\right)\left(\psi_{2 n}-\frac{H_{O K} \zeta_{O K}}{H_{M} \zeta_{M}} \psi_{1 n}\right)-\frac{H_{M} \zeta_{M} \rho_{c}}{2}\left(\psi_{2 n}-\frac{H_{O K} \zeta_{O K}}{H_{M} \zeta_{M}} \psi_{1 n}\right)^{2}\right]= \\
& =\frac{\lambda_{C} K_{2} C_{O_{2}}^{m} \cdot \bar{\rho}_{2}^{n} R T_{n}^{2}}{E_{2}} e^{-E_{2} /\left(R T_{n}\right)} \cdot\left[1-e^{-\frac{E_{2} \cdot\left(T_{n}-T_{0}\right)}{R T_{n}^{2}}}\right]-\frac{\lambda_{C} K_{1} R T_{n}^{2} H_{O K} \zeta_{O K}}{E_{1} H_{M} \zeta_{M}} \cdot e^{-E_{1} /\left(R T_{n}\right)} \cdot\left[1-e^{-\frac{E_{1} \cdot\left(T_{n}-T_{0}\right)}{R T_{n}^{2}}}\right] .
\end{aligned}
$$

отримуємо, що

$$
e^{-E_{i} /(R T)} \cong e^{E_{i} /\left(R T_{n}\right)} \cdot e^{E_{i} \cdot\left(T_{n}-T\right) /\left(R T_{n}^{2}\right)} .
$$

Підставляючи (10) у (8), отримуємо
Проведені оцінки $[9,11]$ показують, що у першому наближенні у виразі (14) можна знехтувати тепловиділенням у реакційній зоні к-фазі суміші в результаті окиснення частинок металу. 3 урахуванням цього факту вираз (14) набуває вигляду

$$
H_{O K} \zeta_{O K} \rho_{c} u^{2} \cdot\left[c_{c}\left(T_{n}-T_{0}\right) \psi_{1 n}+\frac{H_{O K} \zeta_{o K}}{2} \psi_{2 n}^{2}\right]=\frac{\lambda_{c} K_{1} R T_{n}^{2} H_{O K} \zeta_{O K}}{E_{1}} \cdot e^{-E_{1} /\left(R T_{n}\right)} \cdot\left[1-e^{-\frac{E_{1} \cdot\left(T_{n}-T_{0}\right)}{R T_{n}^{2}}}\right] .
$$

При $x=0$ з рівняння (15) отримуємо, що

$$
\begin{aligned}
& \psi_{1 n}=\frac{q_{n}+q_{\kappa}+q_{R}-\rho_{c} c_{c} u\left(T_{n}-T_{0}\right)}{H_{\text {ок }} \rho_{c} u \zeta_{\text {oк }}} . \\
& \rho_{c}^{2} c_{c}^{2} u^{2}\left(T_{n}-T_{0}\right)^{2}=\left(q_{n}+q_{\kappa}+q_{R}\right)^{2}+\frac{2 c_{c} \rho_{c} K_{1} H_{\text {oK }} \zeta_{O K} R T_{n}^{2}}{E_{1}} e^{-E_{1} /\left(R T_{n}\right)} \cdot\left[1-e^{-\frac{E_{1} \cdot\left(T_{n}-T_{0}\right)}{R T_{n}^{2}}}\right] .
\end{aligned}
$$

Підставивши вираз (16) у (15), отримаємо для швидкості горіння наступне

3 урахуванням того, що $\zeta_{\text {ок }}=\frac{l_{c} \alpha}{1+l_{c} \alpha}$ ( $\alpha$ - коефіцієнт надлишку окиснювача; $l_{c}-$ стехіометричний коефіцієнт), остаточно для 


$$
\rho_{c}^{2} c_{c}^{2} u^{2}\left(T_{n}-T_{0}\right)^{2}=\left(q_{n}+q_{K}+q_{R}\right)^{2}+\frac{2 c_{c} \rho_{c} K_{1} H_{O K} \alpha \zeta_{o K} R T_{n}^{2}}{E_{1}\left(1+l_{c} \alpha\right)} e^{-E_{1} /\left(R T_{n}\right)} \cdot\left[1-e^{-\frac{E_{1} \cdot\left(T_{n}-T_{0}\right)}{R T_{n}^{2}}}\right] .
$$

Далі з отриманого спрощеного рівняння (18) випливає, що для розрахунку швидкості горіння сумішей необхідно знати параметри $T_{n}, q_{n}, q_{\kappa}, q_{R}$.

Визначення $T_{n}$. Експериментальне визначення $T_{n}$ існуючими методами $є$ складним і достатньо наближеним $[8,9,11]$, а дослідження, які присвячені аналітичному визначенню $T_{n}$, нині обмежені. Тому, використовуючи

$$
\frac{\rho_{c} u^{2} l_{c} \alpha H_{O K}}{1+l_{c} \cdot \alpha}\left[c_{c}\left(T_{n}-T_{0}\right)+\frac{l_{c} \alpha H_{O K}}{2\left(1+l_{c} \cdot \alpha\right)}\right]=\frac{\lambda_{c} K_{1} H_{O K} l_{c} \alpha R T_{n}^{2}}{1+l_{c} \alpha} e^{-E_{1} /\left(R T_{n}\right)} \cdot\left[1-e^{-\frac{E_{1} \cdot\left(T_{n}-T_{0}\right)}{R T_{n}^{2}}}\right] .
$$

Рівняння (13)-(19) замикають вихідну систему рівнянь для розрахунку швидкості та температури поверхні горіння сумішей.

Проведені експериментальні дослідження $[11,16,19]$ показують, що для піротехнічних нітратно-металевих сумішей тепловий потік $q_{n}$ перевищує теплові потоки $q_{\kappa}$ та $q_{R}$ більше, ніж на порядок $\left(q_{\kappa} \cdot q_{R}<<q_{n}\right)$. Тому у рівняннях (18) та (19) потоками $q_{\kappa}$ та $q_{R}$ нехтуємо порівняно $3 q_{n}$.

Визначення $q_{n}$. 3 даних мікрозйомки [9, 11] поверхні сумішей, наприклад $\mathrm{Ti}+\mathrm{NaNO}_{3}$, випливає, що значна частина частинок металу в результаті їх послідовного оплавлення (аг-

ломерації) (рисунок 5) повністю згоряють у дифузійному режимі у газоподібних продуктах розкладання окиснювача при температуpax $T_{n}$ (рисунок 6). В результаті математичної обробки численних кінограм процесу горіння сумішей для аналітичних розрахунків величин $q_{n}$ було отримано вираз (відносна похибка $5 \ldots 7 \%)$

$$
q_{n}=\frac{\rho_{c} d_{M} H_{M} \cdot \sum_{k=0}^{6} b_{k} \cdot \alpha^{k}}{\left(1+l_{c} \cdot \alpha\right) \tau_{2}},
$$

де параметри $b_{k}(k=\overline{1,6})$ - емпіричні константи (таблиця 1);

$$
\tau_{2}=B_{0}+B_{1} C_{O_{2}}+B_{2} C_{O_{2}}^{2}+B_{3} \frac{d_{M}}{P}+B_{4} P^{B_{5}}\left(C_{O_{2}}+B_{6}\right)^{-1},
$$

де $\tau_{2}$ - час згоряння частинок порошка Ті у газоподібних продуктах розкладання нітрату натрію (відносна концентрація $\mathrm{O}_{2}$ у продуктах розкладання $C_{O_{2}}=0,2 \ldots 1,0 ;$ зовнішній тиск
$P=10^{5} \ldots 10^{7}$ Па; дисперсність металу $d_{M}=45 \ldots 280$ мкм); $\overline{B_{0}, \ldots B_{6}}-$ емпіричні константи (таблиця 2).

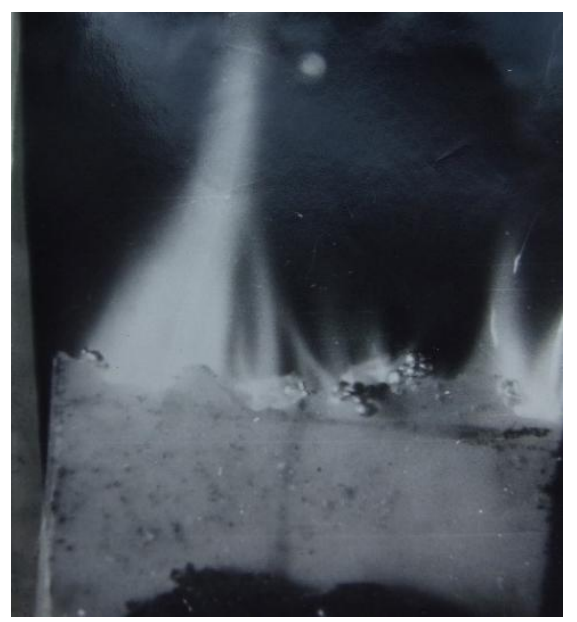

(мікрозйомка процесу горіння здійснювалася кінокамерою СКС-1М (швидкість зйомки - 3000...5000 кадр/с))

Рисунок 5 - Кінокадри швидкісної мікрозйомки процесу агломерації металевого пального на поверхні горіння піротехнічних нітратно-металевих сумішей

(C) О. С. Діброва, О. В. Кириченко, Р. Б. Мотрічук, В. А. Ващенко, С. О. Колінько, Т. І. Бутенко, В. В. Цибулін, 2020 DOI: $10.24025 / 2306-4412.2 .2020 .197339$ 
A

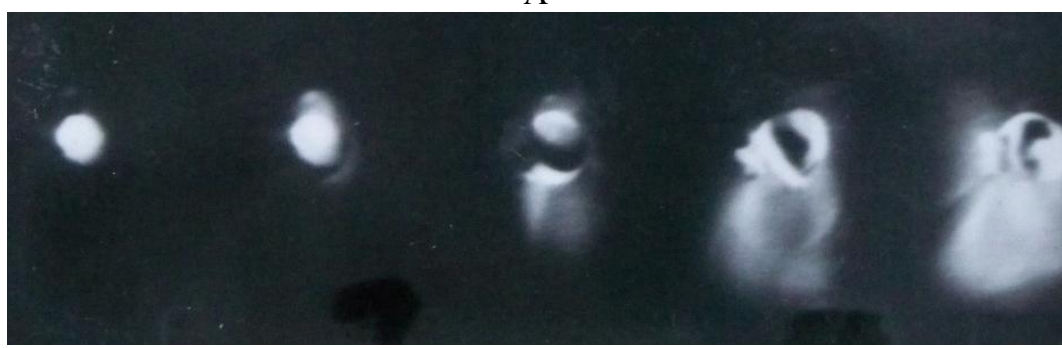

2

4

5

B

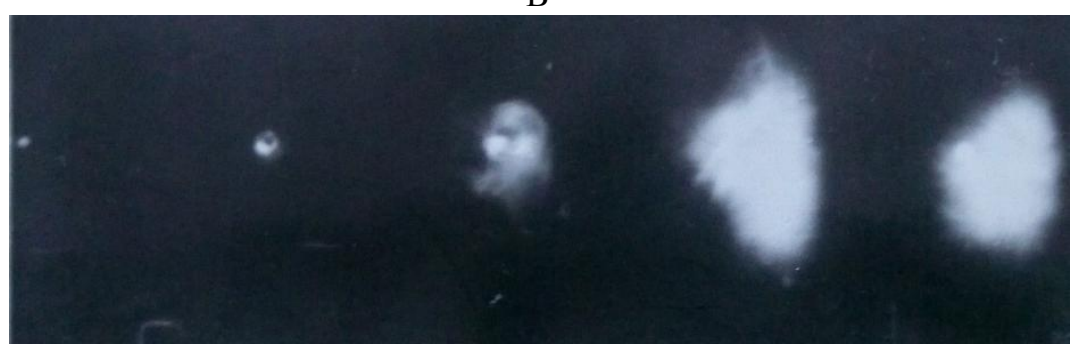

$\begin{array}{lllll}1 & 2 & 3 & 4 & 5\end{array}$

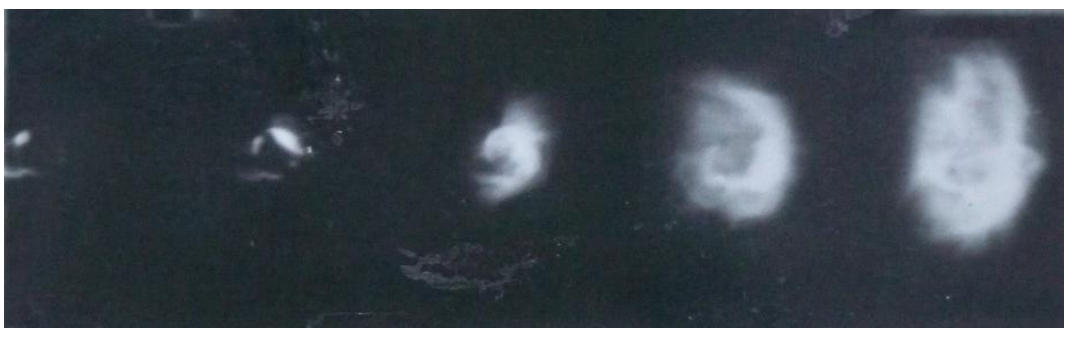

6

7

8

9

10

А - знімки $1,2,3,4,5$ для частинок Ті з розміром $d_{M}=100$ мкм у потоці $\mathrm{O}_{2}$ (початкова стадія розкладання окиснювача); В - знімки $1,2,3,4,5$ для частинок Ті з $d_{M}=45$ мкм та 6, 7, 8, 9, 10 $3 d_{M}=100$ мкм у потоці $\mathrm{O}_{2}+\mathrm{N}_{2}$ (повне розкладання окиснювача при температурах $T_{n}$ )

Рисунок 6 - Кінокадри швидкісної мікрозйомки процесів вимушеного спалахування

та подальшого розвитку горіння частинок Ті у газоподібних продуктах розкладання нітратовмісного окиснювача $\left(\mathrm{NaNO}_{3}, \mathrm{Ba}\left(\mathrm{NO}_{3}\right)_{2}, \mathrm{Sr}\left(\mathrm{NO}_{3}\right)_{2}\right.$ та ін.) при температурах, відповідних температурі поверхні горіння сумішей $T_{n}$

Наведені вище рівняння (18)-(21) дають змогу розраховувати час згоряння частинок металевого пального у потоці газоподібних продуктів розкладання окиснювача $\tau_{2}$ на поверхні горіння суміші, тепловий потік з цієї поверхні $q_{n}$ та швидкість їх горіння $u$.

Результати розрахунків на комп'ютері 3 використанням стандартного програмного забезпечення [9] за формулою (21) з долученням усіх необхідних даних для нітратнотитанових сумішей $[6-9,11]$ показують (рисунок 7), що: збільшення $d_{m}$ призводить до помітного зростання $\tau_{2}$ (у 4...6 разів), а збільшення $C_{O_{2}}$ та $P$ - до зменшення $\tau_{2}$ у $1,8 \ldots 3,2$ разу (для $C_{O_{2}}$ ) та у $1,6 \ldots 3,3$ разу (для $P$ ). При цьому, в результаті проведених досліджень для використовуваних на практиці діапазонів зміни розглядуваних параметрів $\left(d_{M}=45 \ldots 280\right.$ мкм; $\quad C_{O_{2}}=0,2 \ldots 0,4 \quad$ та $P=10^{5} \ldots 10^{7}$ Па) процес горіння частинок титану проходить стабільно без вибухових фрагментацій.

Результати розрахунків за формулою (20) показують, що тепловий потік $q_{n}$ найбільш суттєво залежить від коефіцієнта надлишку окиснювача (рисунок 8): так, при зміні $\alpha$ в діапазонах $0,3<\alpha<1,4$ величина $q_{n}$ різко зменшується аж до нуля, тобто, починаючи 3 певних значень $\alpha>1$, частинки металу вже не затримуються на поверхні горіння, а починають інтенсивно відноситися в зону полум'я разом 3 частинками розплаву окиснювача, що не розклалися.

(C) О. С. Діброва, О. В. Кириченко, Р. Б. Мотрічук, В. А. Ващенко, С. О. Колінько, Т. І. Бутенко, В. В. Цибулін, 2020 DOI: $10.24025 / 2306-4412.2 .2020 .197339$ 
Це приводить до нестійкості та різкого затухання процесу горіння сумішей, що супроводжується викидом у навколишнє середовище великої кількості розжарених продуктів (частин суміші, що не згоріли, фрагментів металевих корпусів тощо), які є пожежонебезпечними для оточуючих об'єктів.

За отриманими вище рівняннями (18)(21) було проведено розрахунки залежностей швидкості горіння сумішей від технологічних параметрів (коефіцієнта надлишку окиснювача, дисперсності металевого пального) і зовнішніх впливів (підвищених температур нагріву, зовнішніх тисків) (рисунок 9).

3 результатів зіставлення розрахункових залежностей 3 експериментальними даними [9] випливає, що між ними спостерігається повний якісний збіг, що відповідає за- пропонованому вище механізму горіння сумішей. Щодо кількісних відмінностей між розрахунком та експериментом, то вони не перевищують $8 \ldots 10 \%$.

Крім цього, в результаті проведених розрахунків було встановлено наступні критичні діапазони зміни швидкості горіння сумішей, перевищення яких призводить до нестабільного вибухонебезпечного розвитку процесу їх горіння в умовах зовнішніх термодій:

$$
u_{2}^{* *} \leq u \leq u_{1}^{*}, T_{2}^{* *} \leq T_{n} \leq T_{1}^{*},
$$

де $\quad u_{1}^{*}=1,2 \cdot 10^{-2} \mathrm{M} / \mathrm{c}, \quad u_{2}^{* *}=1,2 \cdot 10^{-2} \mathrm{M} / \mathrm{c}$, $T_{1}^{*}=1050 \mathrm{~K}, T_{2}^{* *}=1160 \mathrm{~K}-$ гранично допустимі значення параметрів, що визначають критичні режими розвитку горіння сумішей в умовах зовнішніх термічних дій.

Таблиця 1 - Значення емпіричних коефіціснтів у формулі (20) для суміші $\mathrm{Ti}+\mathrm{NaNO}_{3}$

\begin{tabular}{|c|c|c|c|c|c|c|c|}
\hline Коефіцієнт & $A_{0}$ & $A_{1}$ & $A_{2}$ & $A_{3}$ & $A_{4}$ & $A_{5}$ & $A_{6}$ \\
\hline Значення & 0 & 0 & 0 & 0 & 73,289 & $-127,413$ & 47,541 \\
\hline
\end{tabular}

Таблиця 2 - Значення емпіричних коефіцієнтів у формулі (21) для суміші $\mathrm{Ti}+\mathrm{NaNO}_{3}$

\begin{tabular}{|c|c|c|c|c|c|c|c|}
\hline Коефіцієнт & $B_{0}$ & $B_{1}$ & $B_{2}$ & $B_{3}$ & $B_{4}$ & $B_{5}$ & $B_{6}$ \\
\hline Значення & 1,12 & 1,31 & $2,61 \cdot 10^{-2}$ & $10^{-4}$ & 0,19 & 0,6 & 0,3 \\
\hline
\end{tabular}

Таким чином, розроблена математична модель горіння піротехнічних нітратнометалевих сумішей дає змогу на стадії проектування та подальших стендових випробувань піротехнічних виробів визначати 3 точністю $8 . .10 \%$ вплив підвищених температур нагріву та зовнішніх тисків (для широкого діапазону зміни співвідношень компонентів та дисперсності) на швидкість, а також критичні режими стійкого розповсюдження горіння в умовах термічного впливу. Це дає можливість прогнозувати різні пожежонебезпечні ситуації, що виникають в умовах зовнішніх термодій, яким піддаються вироби при їх експлуатації.

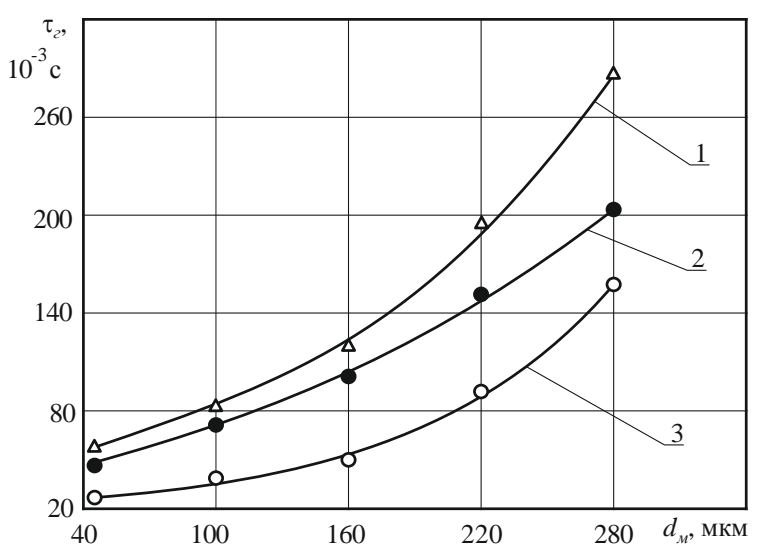

a)

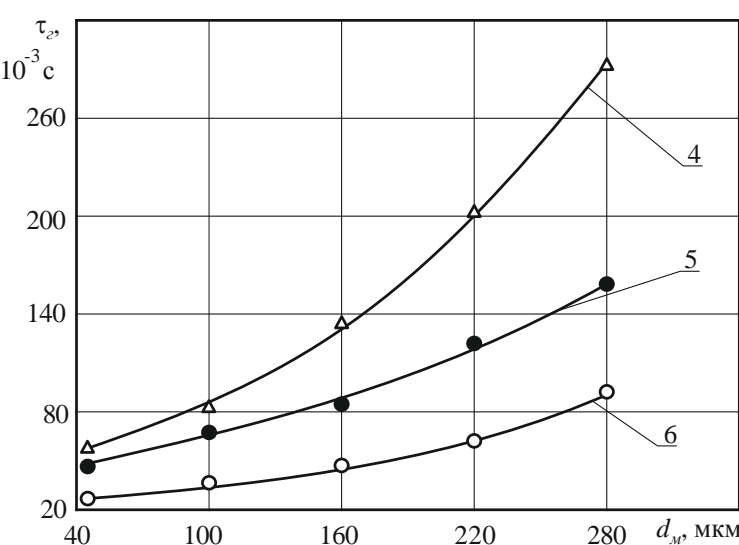

б)

a) $T_{n}=1050 \mathrm{~K}, P=10^{5}$ Па, $1-C_{O_{2}}=0,2,2-C_{O_{2}}=0,6,3-C_{O_{2}}=0,8 ;$ б) $T_{n}=1100 \mathrm{~K}, C_{O_{2}}=0,2$, $4-P=10^{5}$ Па, $5-P=10^{6}$ Па, $6-P=10^{7}$ Па; $\Delta, \circ, \bullet-$ експериментальні дані

Рисунок 7 - Залежність часу згоряння частинок титану у газовому середовищі $\mathrm{O}_{2}+\mathrm{N}_{2}$ від їх розміру для різних відносних масових концентрацій кисню (a) та зовнішніх тисків (б)

() О. С. Діброва, О. В. Кириченко, Р. Б. Мотрічук, В. А. Ващенко, С. О. Колінько, Т. І. Бутенко, В. В. Цибулін, 2020 DOI: $10.24025 / 2306-4412.2 .2020 .197339$ 


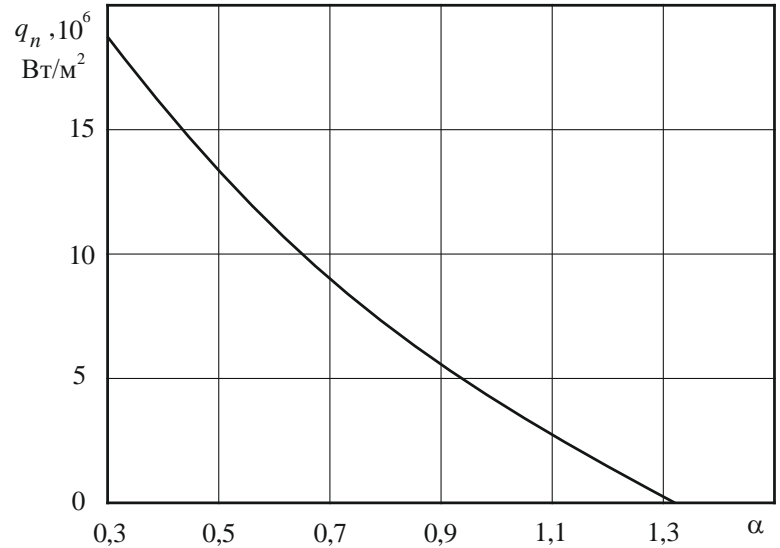

Рисунок 8 - Залежність теплового потоку $q_{n}$ від коефіцієнта надлишку окиснювача для нітратно-титанової суміші

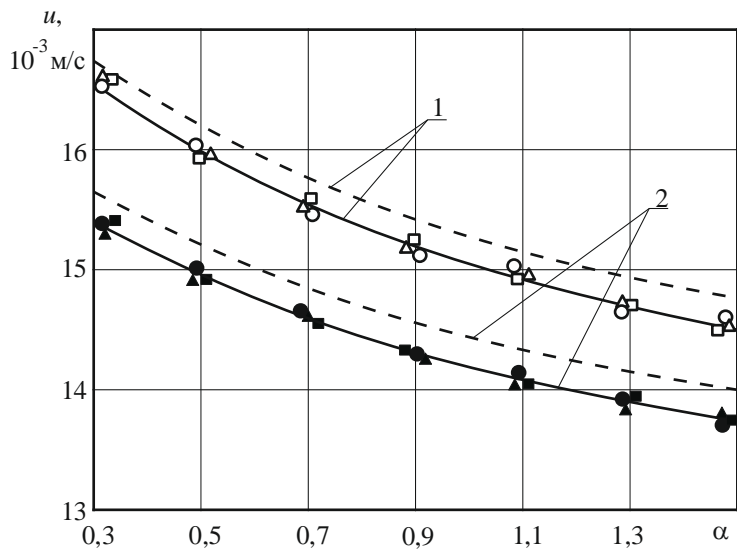

a)

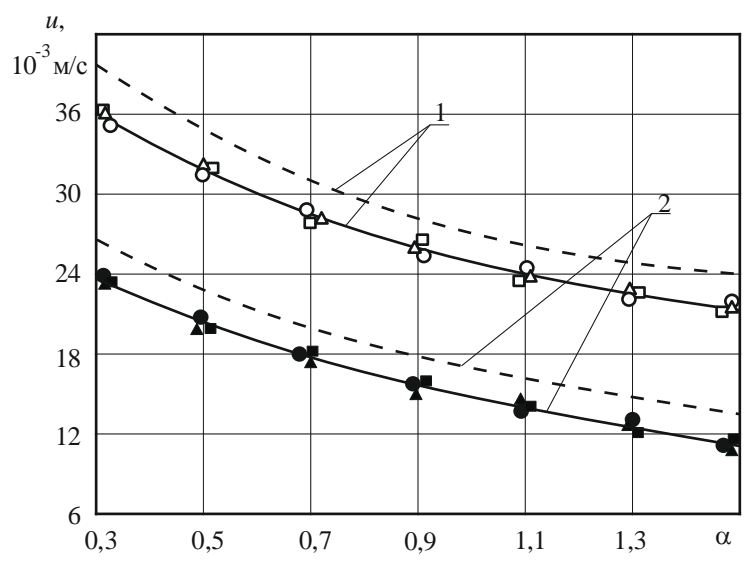

б)

a) вплив $T_{0}\left(1-T_{0}=800 \mathrm{~K} ; 2-T_{0}=400 \mathrm{~K} ; d_{M}=45\right.$ мкм; $P=10^{5}$ Па $) ;$ б) вплив $P\left(3-P=10^{7}\right.$ Па; $4-P=10^{5}$ Па; $T_{0}=300 \mathrm{~K} ; d_{M}=135$ мкм) - - - розрахункова крива; — - експериментальна крива; $\mathbf{\square}, \square, \Delta, \boldsymbol{\Delta}$ ○, • - експериментальні дані

Рисунок 9 - Залежності швидкості горіння суміші $\mathrm{Ti}+\mathrm{NaNO}_{3}$ від коефіціснта надлишку окиснювача для різних температур нагріву $T_{0}$ та зовнішніх тисків $P$

\section{Висновки:}

1. Встановлено механізм та розроблено математичні моделі процесу горіння піротехнічних нітратно-металевих сумішей, в яких використовуються кінетичні характеристики процесів термічного розкладання окиснювача, високотемпературного окиснення, займання та горіння частинок металевого пального на поверхні горіння сумішей.

2. На прикладі нітратно-титанових сумішей показано, що моделі з відносною похибкою $8 \ldots 10 \%$ дають можливість визначати залежності швидкості розвитку процесу горіння сумішей від параметрів зовнішніх термічних дій (підвищені температури нагріву i зовнішні тиски) для різних значень їх технологічних параметрів (співвідношення компонентів та дисперсності), що дає можливість знаходити критичні режими горіння, переви- щення яких призводить до вибухонебезпечного руйнування піротехнічних виробів.

\section{Список використаних джерел}

[1] К. О. Брауэр, "Пиротехнические устройства для космических аппаратов", Вопросы ракетной техники, вып. 10, с. 47-61, 1969.

[2] А. А. Шидловский, Основы пиротехники. Москва: Машиностроение, 1973.

[3] А. А. Шидловский, А. И. Сидоров, и Н. А. Силин, Пиротехника в народном хозяйстве. Москва: Машиностроение, 1978.

[4] В. В. Тарасов, и Ю. Г. Якушенков, Инфракрасные системь “смотрящего” типа. Москва: Логос, 2004.

(ㄷ) О. С. Діброва, О. В. Кириченко, Р. Б. Мотрічук, В. А. Ващенко, С. О. Колінько, Т. І. Бутенко, В. В. Цибулін, 2020 DOI: 10.24025/2306-4412.2.2020.197339 
[5] А. Р. Глущенко, В. И. Гордиенко, А. В. Бурак, и А. Ю. Денисенко, Танковые ночные системы и приборы наблюдения. Черкассы: Фотоприбор, 2007.

[6] Н. А. Силин, В. А. Ващенко, Л. Я. Кашпоров и др., Металлические горючие гетерогенных конденсированных систем. Москва: Машиностроение, 1976.

[7] Н. А. Силин, В. А. Ващенко, Н. И. Зарипов и др., Окислители гетерогенных конденсированных систем. Москва: Машиностроение, 1978.

[8] Н. А. Силин, В. А. Ващенко, Л. Я. Кашпоров и др., Горение металлизированных гетерогенных конденсированных систем. Москва: Машиностроение, 1982.

[9] В. А. Ващенко, О. В. Кириченко, Ю. Г. Лега, П. И. Заика, И. В. Яценко, и В. В. Цыбулин, Проиессы горения металлизированных конденсированных систем. Київ: Наукова думка, 2008.

[10] В. А. Ващенко,

О. В. Кириченко, В. Д. Акиньшин, В. В. Цыбулин, и И. В. Яценко, "Комплекс испытательных установок, моделирующих реальные условия применения пиротехнических нитратосодержащих изделий", Науковий вісник УкрНДІПБ, № 1(19), с. 127-137, 2009.

[11] О. В. Кириченко, П. С. Пашковський, В. А. Ващенко, та Ю. Г. Лега, Основи пожежної безпеки піротехнічних нітратовмісних виробів в умовах зовнішніх термовпливів. Київ: Наукова думка, 2012.

[12] О. В.Кириченко, "Скорость и предельные режимы горения трехкомпонентных пиротехнических смесей в условиях внешних термовоздействий", Пожаровзрывобезопасность: междунар. науч.практ. журн., № 5, с. 20-25, 2013.

[13] О. В. Кириченко, "Влияние повышенных температур нагрева и внешних давлений на скорость и предельные режимы горения пиротехнических нитратноалюминиевых смесей", Чрезвычайные ситуации: промышленная и экологическая безопасность: междунар. науч.практ. журн., № 2, с. 18-23, 2013.

[14] О. В. Кириченко, О. С. Діброва, Р. Б. Мотрічук, В. А. Ващенко, С. О. Колінько, та В. В. Цибулін, "Дослідження впливу міцності зарядів піротехнічних нітратнометалевих сумішей на пожежну безпеку виробів на їх основі", Вісник Черкаського державного технологічного університе$m y$, № 3, с. 56-67, 2019.

[15] О. В. Кириченко, "Термодинамічні методи прогнозування пожежонебезпечних властивостей піротехнічних нітратномагнієвих сумішей", Пожежна безпека: теорія і практика: зб. наук. праць АПБ ім. Героїв Чорнобиля, № 7, с. 59-67, 2011.

[16] В. А. Ващенко, П. И. Заика, О. В. Кириченко, С. В. Щепак, и А. Д. Блащук, "Исследование интенсивности диспергирования частиц магния в зону пламени при горении нитратно-магниевых систем", Пожежна безпека: теорія і практика: зб. наук. праць АПБ ім. Героїв Чорнобиля, № 7, с. 27-30, 2011.

[17] О. В. Кириченко, В. Д. Акіньшин, В. А. Ващенко, та В. В. Цибулін, "Термодинамічні методи прогнозування пожежонебезпечних властивостей високометалізованих піротехнічних нітратнометалічних сумішей в умовах зовнішніх термо-впливів", Проблемы пожарной безопасности, № 30, с. 104-106, 2011.

[18] О. В. Кириченко, "Математичне моделювання процесу нагріву металевих корпусів піротехнічних виробів в умовах пострілу та польоту", Науковий вісник УкрНДІЦЗ, № 1 (27), с. 173-186, 2013.

[19] О.В. Кириченко, В. А. Ващенко, В. В. Цибулін, та В. М. Тупицький, "Швидкість та межі горіння піротехнічних нітратномагнієвих сумішей в умовах зовнішніх термовпливів", Проблемы пожарной безопасности, № 34, с. 73-95, 2013.

[20] О.В. Кириченко, "Моделирование процесса нагрева металлических оболочек пиротехнических изделий в условиях внешних термовоздействий", Чрезвычайные ситуации: образование и наука: междунар. науч.-практ. журн., № 2, с. 37-45, 2013.

\section{References}

[1] K. O. Brower, "Pyrotechnic devices for spacecraft". Voprosy raketnoi techniki, iss. 10, pp. 47-61, 1969 [in Russian].

[2] A. A. Shidlovskii, Bases of pyrotechnics. Moscow: Mashinostroenie, 1973 [in Russian].

[3] A. A. Shidlovskii, A. I. Sidorov, and N. A. Silin, Pyrotechnics in the national 
economy. Moscow: Mashinostroenie, 1978 [in Russian].

[4] V. V. Tarasov, and Yu. G. Yakushenkov, "Looking" type infrared systems. Moscow: Logos, 2004 [in Russian].

[5] A. R. Glushchenko, V. I. Gordienko, A. V. Burak, and A. Yu. Denisenko, Tank night systems and surveillance devices. Cherkassy: Fotopribor, 2007 [in Russian].

[6] N. A. Silin, V. A. Vaschenko, and L. Ya. Kashporov, Metal fuels of heterogeneous condensed systems. Moscow: Mashinostroenie, 1976 [in Russian].

[7] N. A. Silin, V. A. Vashchenko, N. I. Zaripov et al., Oxidizers of heterogeneous condensed systems. Moscow: Mashinostroenie, 1978 [in Russian].

[8] N. A. Silin, V. A. Vaschenko, L. Ya. Kashporov et al., Combustion of metalized heterogeneous condensed systems. Moscow: Mashinostroenie, 1982 [in Russian].

[9] V. A. Vashchenko, O. V. Kirichenko, Yu. G. Lega, P. I. Zaika, I. V. Yatsenko, and V.V. Tsybulin, Combustion processes of metallized condensed systems. Kyiv: Naukova dumka, 2008 [in Russian].

[10] V. A. Vashchenko, O. V. Kirichenko, V. D. Akinshin, V. V. Tsybulin, and I. V. Yatsenko, "A complex of test installations simulating real conditions for the use of pyrotechnic nitrate-containing products", Naukovyy visnyk Ukrayinskoho naukovodoslidnoho instytutu pozhezhnoyi bezpeky, no. 1(19), pp. 127-137, 2009 [in Russian].

[11] O. V. Kirichenko, P. S. Pashkovsky, V. A. Vaschenko, and Yu. G. Lega, The basis of fire safety of pyrotechnic nitratecontaining products in the conditions of external thermal influences. Kyiv: Naukova dumka, 2012 [in Ukrainian].

[12] O. V. Kirichenko, "Velocity and limit combustion regimes of three-component pyrotechnic mixtures under external thermal influences", Pozharovzryvobezopasnost, no. 5, pp. 20-25, 2013 [in Russian].

[13] O. V. Kirichenko, "The effect of elevated heating temperatures and external pressures on the speed and limit combustion conditions of pyrotechnic nitrate-aluminum mixtures", Chrezvychaynyye situatsii: promyshlennaya $i$ ekologicheskaya bezopasnost, no. 2, pp. 18-23, 2013 [in Russian].
[14] O. V. Kirichenko, O. S. Dibrova, R. B. Motrichuk, V. A. Vaschenko, S. O. Kolinko, and V. V. Tsybulin, "Investigation of the effect of charge strength of pyrotechnic nitrate-metal mixtures on the fire safety of products based on them", Visnyk Cherkaskogo derzhavnogo tehnologichnogo universitetu, no. 3, pp. 56-67, 2019 [in Ukrainian].

[15] O. V. Kirichenko, "Thermodynamic methods for predicting the fire-fighting properties of pyrotechnic nitrate-magnesium mixtures", Pozhezhna bezpeka: teoriya i prakty$k a$ : coll. of sci. papers of Cherkasy Chernobyl Hero Fire Academy, no. 7, pp. 59-67, 2011 [in Ukrainian].

[16] V. A. Vaschenko, P. I. Zaika, O. V. Kirichenko, S. V. Schepak, and A. D. Blaschuk, "Study of the intensity of dispersion of magnesium particles into the flame zone during combustion of nitrate-magnesium systems", Pozhezhna bezpeka: teoriya i praktyka: coll. of sci. papers of Cherkasy Chernobyl Hero Fire Academy, no. 7, pp. 27-30, 2011 [in Russian].

[17] O. V. Kirichenko, V. D. Akinshin, V. A. Vashchenko, and V.V. Tsybulin, "Thermodynamic methods for predicting the fire properties of highly metallized pyrotechnic nitrate-metal mixtures under conditions of external thermal influences", Problemy pozharnoy bezopasnosti, no. 30, pp. 104-106, 2011 [in Ukrainian].

[18] O. V. Kirichenko, "Mathematical modeling of the process of heating of metal housings of pyrotechnic articles under conditions of shot and flight", Naukovyy visnyk Ukrayinskoho naukovo-doslidnoho instytutu tsyvilnoho zakhystu, no. 1 (27), pp. 173-186, 2013 [in Ukrainian].

[19] O. V. Kirichenko, V. A. Vashchenko, V. V. Tsybulin, and V. M. Tupitsky, "Speed and limits of combustion of pyrotechnic nitrate-magnesium mixtures under conditions of external thermal influences", Problemy pozharnoy bezopasnosti, no. 34, pp. 73-95, 2013 [in Ukrainian].

[20] O. V. Kirichenko, "Modeling the heating process of metal shells of pyrotechnic products in conditions of external thermal effects", Chrezvychaynyye situatsii: obrazovaniye i nauka, no. 2, pp. 37-45, 2013 [in Russian]. 


\section{O. S. Dibrova, \\ National University of Civil Defense of Ukraine Chernycshevskyi str., 94, Kharkiv, 61023, Ukraine \\ O. V. Kirichenko, Dr.Tech.Sc., professor, \\ R. B. Motrichuk, \\ Cherkasy Institute of Fire Safety, Onoprienko str., 8, Cherkasy, 18034, Ukraine \\ V. A. Vaschenko, Dr.Tech.Sc., professor, \\ S. O. Kolinko, Ph. D., associate professor, \\ T. I. Butenko, $P h$. D., associate professor, V. V. Tsybulin \\ Cherkasy State Technological University \\ Shevchenko blvd, 460, Cherkasy, 18006, Ukraine \\ DETERMINATION OF CRITICAL MODES FOR THE DEVELOPMENT OF COMBUSTION PROCESSES OF PYROTECHNICAL NITRATE-METAL MIXTURES UNDER CONDITIONS OF EXTERNAL THERMAL ACTIONS}

Currently, models of combustion of mixtures based on $\mathrm{Mg}+\mathrm{NaNO}_{3}$ have been developed and investigated in detail to calculate the combustion rates of pyrotechnic mixtures. As for other pyrotechnic mixtures, the results of theoretical studies on the modeling of their combustion processes under different external conditions are very limited, and in most cases absent. The purpose of this work is to develop a model of combustion of compacted mixtures of Ti powders and nitrate-containing oxidizing agent $\left(\mathrm{NaNO}_{3}, \mathrm{Ba}\left(\mathrm{NO}_{3}\right)_{2}, \mathrm{Sr}\left(\mathrm{NO}_{3}\right)_{2}\right)$ to determine the critical modes of their persecution by calculating the dependence of the propagation of the combustion front on charges and technological factors conditions. Developed mathematical model of combustion of pyrotechnic nitrate-metal mixtures allows to determine with accuracy of $8 \ldots 10 \%$ the influence of high heating temperatures and external pressures (for a wide range of change of component ratios and dispersion) on the stage of design and subsequent bench testing of pyrotechnic articles with precision and dispersion, sustainable propagation of combustion in conditions of thermal impact. This makes it possible to predict different fire situations that occur in the external thermodynamic conditions to which the products are exposed during their operation. The mechanism is established and mathematical models of the pyrotechnic nitratemetal combustion process are used, which use kinetic characteristics of the processes of thermal decomposition of oxidizer, high-temperature oxidation, ignition and combustion of metal fuel particles on the combustion surface of the mixtures. The example of nitrate-titanium mixtures shows that models with a relative error of $8 . .10 \%$ allow to determine the dependence of the rate of development of the combustion process of the mixture on the parameters of external thermal actions (increased heating temperatures and external pressures) for different values of their technological parameters (the ratio of components and dispersion), which makes it possible to find critical modes of combustion, the excess of which leads to the explosive destruction of pyrotechnic articles.

Keywords: pyrotechnic mixtures, nitrate-containing oxidizer, metal fuel, combustion processes, fire safety.

Стаття надійшла 28.01.2020

Прийнято 18.02.2020

(C) О. С. Діброва, О. В. Кириченко, Р. Б. Мотрічук, В. А. Ващенко, С. О. Колінько, Т. І. Бутенко, В. В. Цибулін, 2020 DOI: $10.24025 / 2306-4412.2 .2020 .197339$ 